\title{
Dampak Cuaca Ekstrim terhadap Kehampaan Genotipe Padi: Pengantar Manajemen Produksi Berbasis Iklim
}

\section{Impact of Extreme Weather on Grain Sterility of Rice Genotypes: An Introduction to Production Management Based on Climate}

\author{
Purwono $^{1 *}$, Dulbari ${ }^{2}$, dan Edi Santosa ${ }^{1}$ \\ ${ }^{1}$ Departemen Agronomi dan Hortikultura, Fakultas Pertanian, Institut Pertanian Bogor \\ (IPB University), Jl. Meranti, Kampus IPB Darmaga, Bogor 16680, Indonesia \\ ${ }^{2}$ Jurusan Agroteknologi, Politeknik Negeri Lampung \\ Jl. Soekarno Hatta 10 Rajabasa, Bandar Lampung 35144, Indonesia
}

Diterima 10 Juni 2021/Disetujui 22 Juli 2021

\begin{abstract}
Sterility in rice genotypes associated with strong wind and high rainfall incidents is still rarely studied in Indonesia. The study aimed to evaluate the sterility level of rice genotypes to the wind and rainfall treatments during the generative stage. The research was conducted at the Leuwikopo IPB Experimental Station, Bogor, Indonesia in October 2017-January 2018 using plants grown in a container 13.9 L. Genotypes of Ciapus, Fatmawati, HIPA 6, Inpari 10, and Way Apo Buru (WAB) were treated with wind of 10-40 $\mathrm{km} \mathrm{h}^{-1}$ (07.00-17.00 WIB) using axial fan and rain about $100 \mathrm{~mm} \mathrm{~h}^{-1}$ (Rain_712, 07.00-12.00 WIB, and Rain 717, 07.00-17.00 WIB) using sprinklers in the early generative phase for two weeks. Wind and rain treatments increased the number of rice sterility, and the degree of sterility depended on the genotype. In general, plants receiving rain treatment at 07.00-17.00 had a higher percentage of empty unhulled grain than 07.00-12.00, especially for WAB. WAB was sensitive to rainfall, while Ciapus, HIPA 6, and Inpari 10 were more sensitive to wind. The Fatmawati genotype seemed more resistant to both wind and rainfall treatment than the other genotypes. Research shows the need to select rice genotypes to minimize the sterility of wind and high rainfall stress.
\end{abstract}

Keywords: climate change adaptation, precipitation, Oryza sativa, smart climate, strong wind

\section{ABSTRAK}

Kajian kehampaan gabah pada berbagai varietas padi dikaitkan dengan deraan angin dan curah hujan tinggi masih jarang dilakukan di Indonesia. Penelitian bertujuan mengevaluasi tingkat kehampaan beberapa genotipe padi pada perlakuan angin dan hujan selama masa generatif. Penelitian dilaksanakan di Kebun Percobaan IPB Leuwikopo, Bogor, Indonesia pada Oktober 2017-Januari 2018 menggunakan pot ember ukuran 13.9 L. Genotipe Ciapus, Fatmawati, HIPA 6, Inpari 10, dan Way Apo Buru (WAB) pada fase generatif didera angin kecepatan 10-40 $\mathrm{km} \mathrm{jam}^{-1}$ pukul 07.00-17.00 WIB, hujan pukul 07.0012.00 WIB, dan hujan pukul 07.00-17.00 WIB selama dua minggu. Perlakuan angin dan hujan meningkatkan jumlah gabah hampa, dengan tingkat kehampaan malai tergantung genotipe. Tanaman memperoleh perlakuan hujan pukul 07.00-17.00 memiliki persen gabah hampa lebih besar dari hujan pukul 07.00-12.00 khususnya pada genotipe WAB. Kehampaan malai pada genotipe WAB sensitif terhadap curah hujan, dan Ciapus, HIPA 6 dan Inpari 10 sensitif terhadap angin. Fatmawati relatif lebih tahan deraan angin dan hujan dibandingkan genotipe lain. Penelitian menunjukkan perlunya memilih genotipe untuk mengurangi dampak deraan angin dan curah hujan selama masa generatif.

Kata kunci: adaptasi perubahan iklim, angin kencang, hujan, Oryza sativa, smart climate

\section{PENDAHULUAN}

Perubahan iklim merupakan fenomena global yang dapat berdampak positif maupun negatif pada pertumbuhan dan produksi tanaman pangan, termasuk tanaman padi

* Penulis untuk korespondensi. e-mail: puripb@gmail.com
(Auffhammer et al., 2012; Damira dan Irham, 2020; He et al., 2020; Dulbari et al., 2021). Namun dampak dari kejadian yang mengiringi perubahan iklim berupa cuaca ekstrim khususnya curah hujan tinggi dan angin kencang masih jarang dikaji (Sheikh et al., 2015; Martinez-Vazquez, 2016; Dulbari et al., 2017; Myhre et al., 2019; Jian et al., 2020). 
Dulbari et al. (2017) mencatat kecenderungan peningkatan curah hujan disertai angin kencang yang menyebabkan tanaman padi rebah dan terendam, sehingga keduanya dikategorikan sebagai cekaman abiotik. Menurut Santosa et al. (2016) kejadian cuaca ekstrim diperkirakan mengurangi produksi padi per tahun senilai US \$ 270 juta. Mengingat padi sawah (Oryza sativa L.) merupakan tanaman pangan yang menjadi sumber pendapatan bagi 100 juta petani di Indonesia (BPS, 2020), maka melakukan mitigasi dampak negatif cuaca ekstrim adalah langkah penting untuk menjaga pendapatan petani.

Angin kencang disertai curah hujan tinggi menurunkan produksi padi melalui peningkatan kehampaan (Sridevi dan Chellamuthu, 2015). Guncangan angin menyebabkan gabah rontok, dan bunga padi gagal menyerbuk (Ishimaru et al., 2012; Baker et al., 2014; Martinez-Vazquez, 2016). Tingkat kerugian pertanaman padi akibat angin dipengaruhi oleh genotipe, kecepatan angin, fase pertumbuhan, arsitektur tanaman dan status hara (Onoda dan Anten, 2011; Sridevi dan Chellamuthu, 2015; Martinez-Vazquez, 2016; Santosa et al., 2016). Menurut Nurjani et al. (2013) kejadian angin kencang 6 skala Beaufort (10.8-13.8 $\mathrm{m} \mathrm{s}^{-1}$ atau 38.9-49.7 $\mathrm{km} \mathrm{jam}^{-1}$ ) di Jawa Tengah sebanyak 393-490 kejadian per tahun. Namun mitigasi angin kencang pada genotipe padi di Indonesia masih jarang diteliti. Penelitian bertujuan untuk mengetahui tingkat kehampaan gabah pada genotipe padi akibat deraan angin dan hujan dalam rangka manajemen sistem produksi padi cerdas iklim.

\section{BAHAN DAN METODE}

Percobaan berlokasi di Kebun Percobaan Leuwikopo IPB University (240 m dpl), Darmaga, Bogor dari Oktober 2017-Januari 2018. Tanah menggunakan Latosol Darmaga yang telah digenangi 30 hari sebelum tanam. Tanah asli memiliki $\mathrm{N}$ rendah $(0.27 \%)$, P total rendah (38.02 ppm) dan $\mathrm{K}$ tersedia tinggi (187.62 ppm). Sebelum digenangi, media tanam diberi $20 \mathrm{~g} \mathrm{CaCO}_{3}$ dan pupuk kandang $1 \mathrm{~kg}$ tiap pot. Penanaman dilakukan di pot ember hitam kapasitas $13.9 \mathrm{~L}$ (diameter atas $30 \mathrm{~cm}$, diameter bawah $22 \mathrm{~cm}$, tinggi $26 \mathrm{~cm}$ ), total media tanah $\pm 10 \mathrm{~kg}$.

Percobaan menggunakan lima genotipe padi mewakili kelompok inbrida (Ciapus), VUB (Fatmawati, Inpari 10), hibrida (HIPA 6), dan padi lokal (Way Apo Buru-WAB), yang memiliki perbedaan karakter cukup menonjol (Tabel 1). Dua bibit padi umur 15 hari setelah semai ditanam dalam pot. Ketinggian air dipertahankan selama percobaan setinggi 3-5 $\mathrm{cm}$ di atas permukaan tanah. Hama dan penyakit dikendalikan sesuai kebutuhan menggunakan Mankozeb dan Deltametrin 2\%. Pemupukan menggunakan NPK, yakni $300 \mathrm{~kg}$ Urea, $100 \mathrm{~kg}$ SP-36, dan $100 \mathrm{~kg} \mathrm{KCl} \mathrm{ha-1}$. Seluruh dosis $\mathrm{P}$ dan $\mathrm{K}$ serta $1 / 3$ urea diberikan satu minggu setelah tanam (MST), dan sisa urea diberikan pada 3 MST.

Perlakuan dimulai saat $>80 \%$ tanaman padi berbunga (Gambar 1). Perlakukan dilakukan di dalam rumah plastik selama 2 minggu. Perlakuan terdiri atas kontrol (tanpa perlakuan angin dan tanpa hujan), angin (pukul 07.00-17.00 WIB), Hujan 712 (pukul 07.00-12.00 WIB) dan Hujan 717 (pukul 07.00-17.00 WIB). Durasi perlakuan mengacu pada kejadian angin kencang menurut Nurjani et al. (2013). Perlakuan diulang tiga kali, setiap ulangan memakai 10 pot untuk perlakuan hujan, dan 3 pot untuk perlakuan angin. Setelah perlakuan selesai, tanaman kembali dipelihara di lapang.

Simulasi hujan menggunakan sprinkler yang dipasang $2.0 \mathrm{~m}$ di atas tanaman padi. Nozel sprinkler berupa direct spray dan mist-spray (1.5-2.0 Bar) dengan kapasitas bervariasi $(0.5,1.0,2.0$ dan $4.0 \mathrm{~L}$ per jam) yang disusun zig-zag. Jarak antar nozel $50 \mathrm{~cm}$ x $100 \mathrm{~cm}$. Intensitas hujan diukur setiap hari menggunakan gelas berskala. Intensitas hujan tercatat 86-104 mm per jam dengan rata-rata sekitar $100 \mathrm{~mm}$ per jam atau termasuk hujan ekstrim pada klasifikasi BMKG (Dulbari et al., 2017). Ukuran droplet diestimasi dari diameter pada kertas minyak yakni 0.5-2.0 mm $(95 \%$ droplet berukuran $<0.5 \mathrm{~mm})$. Simulasi angin menggunakan kipas axial type cyclon diameter $90 \mathrm{~cm}$ dengan kecepatan angin efektif 10-40 $\mathrm{km} \mathrm{jam}^{-1}$ (anemometer Mastech 6252A, Myanmar) pada jarak 100-500 $\mathrm{cm}$ dari kipas atau nilai 6

Tabel 1. Deskripsi varietas padi yang digunakan dalam penelitian

\begin{tabular}{lccccc}
\hline Deskripsi & Ciapus & Fatmawati & HIPA 6 & Inpari 10 & WAB \\
\hline Tipe* & Semi PTB & PTB & Hibrida & PS & PS \\
Umur tanaman (hari)* & $115-122$ & $105-115$ & $101-128$ & $108-116$ & $113-115$ \\
Tinggi tanaman (cm)* & $100-108$ & $95-110$ & $90-120$ & $100-120$ & $105-113$ \\
Jumlah anakan produktif* & $14-16$ & $8-14$ & $7-14$ & $17-25$ & $15-18$ \\
Kerontokan* & Sedang & Sedang & Mudah & Sedang & Sedang \\
Kerebahan* & Agak tahan & Sedang & Tahan & Tahan & Sedang \\
Rata-rata GKG (ton ha-1)* & 6.5 & 6.0 & 7.4 & 5.1 & 5.5 \\
Jumlah gabah per malai** & 148.6 & 242.8 & 246.4 & 130.0 & 118.2 \\
Kapasitas recovery $(\%)^{* *}$ & 99 & 99 & 60 & ta & 85 \\
\hline
\end{tabular}

Keterangan: *Suprihatno et al. (2009); **Dulbari (2018): Kapasitas recovery rebah, kemampuan tegak kembali setelah direbahkan 90'; ta-tidak ada; PTB-tipe baru; PS-padi sawah 


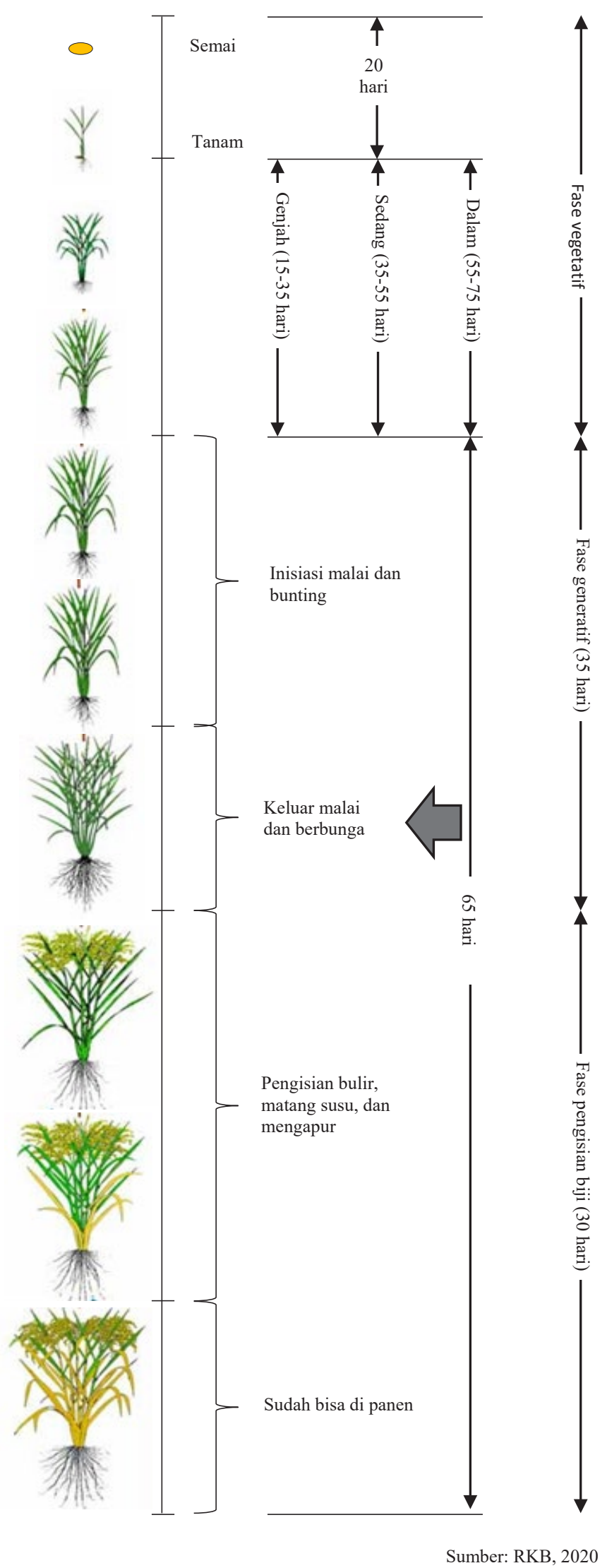

Gambar 1. Fase pertumbuhan dan perkembangan tanaman padi diadopsi dari RKB (2020) dengan modifikasi. Tanda panah adalah stadia tanaman didera perlakuan pada skala Beaufort yakni angin kencang (Dulbari et al., 2017). Kipas dipasang fixed tanpa swing sehingga dihasilkan angin satu arah tertuju pada barisan tanaman padi. Ulangan menggunakan kipas angin terpisah.

Pengamatan meliputi jumlah gabah per malai, persentase gabah hampa, dan bobot gabah per malai. Setiap rumpun diamati 15-20 malai. Data dianalisis menggunakan ANOVA. Jika pengaruh perlakuan nyata dilakukan uji lanjut menggunakan LSD $\alpha=5 \%$.

\section{HASIL DAN PEMBAHASAN}

\section{Pengaruh Langsung dari Angin}

Selama perlakuan angin, batang dan malai padi merunduk searah hembusan angin, namun kecepatan angin hingga $40 \mathrm{~km} \mathrm{jam}^{-1}$ tidak menyebabkan tanaman rebah permanen. Tanaman padi berumpun pendek dan padat memiliki sudut merunduk lebih kecil dibandingkan dengan padi berumpun tinggi dan anakan sedikit. Ada indikasi kuat bahwa keberadaan anakan tidak produktif menghalangi rumpun merunduk. Santosa et al. (2020) menyatakan bahwa tanaman padi yang memiliki banyak anakan tidak produktif nyata lebih tahan rebah dibandingkan dengan yang sedikit anakan berdasarkan uji tekanan statis.

Perlakuan angin tidak menyebabkan abnormalitas pertumbuhan tanaman. Namun, sebagian besar daun bendera dari rumpun yang dekat kipas (kecepatan angin $>30 \mathrm{~km} \mathrm{jam}^{-1}$ ) terbelah pada bagian ujungnya. Selain itu, juga ditemukan adanya padi yang rontok sekitar 5-25 bulir per rumpun (Tabel 2), tanpa memperhatikan genotipe. Bulir yang rontok diduga karena terjadinya benturan antar malai yang terus bergerak selama perlakuan angin. Terkait kerontokan gabah akibat angin perlu kajian lebih lanjut hubungannya dengan arsitektur malai.

\section{Pengaruh Langsung dari Hujan}

Perlakuan hujan menyebabkan abnormalitas malai (Gambar 2). Abnormalitas meliputi pertumbuhan malai, pemencaran malai dan warna sekam. Beberapa malai tumbuh abnormal akibat pelepah daun bendera yang melindungi malai saat masih muda mengalami patah (Gambar 2B). Abnormalitas pertumbuhan tersebut berkontribusi pada peningkatan gabah hampa. Selain itu, ada malai yang muncul tidak lazim yakni melalui sisi bawah pelepah daun bendera, berbeda dengan biasanya yang muncul dari ujung pelepah (Gambar 2A). Konsekuensinya, malai menjadi rusak karena beberapa bulir tersangkut pelepah. Pada penelitian ini tidak dilakukan kuantifikasi abnormalitas pertumbuhan terhadap nilai kehampaan karena kesulitan teknis.

Arsitektur malai cenderung bergerombol pada perlakuan hujan, berbeda dengan tanaman kontrol yang memiliki malai menyebar. Namun demikian, masih perlu penelitian lebih lanjut korelasi arsitektur malai tersebut dengan perlakuan hujan. Malai menggerombol karena sudut 
Purwono et al. / J. Agron. Indonesia 49(2):136-146

Tabel 2. Kejadian daun bendera patah per rumpun tanaman padi setelah perlakuan hujan pada 2 MSP

\begin{tabular}{lccccc}
\hline & \multicolumn{3}{c}{ Kejadian daun bendera patah } & \multicolumn{2}{c}{ Perlakuan angin } \\
\cline { 2 - 6 } Genotipe & $\mathrm{K}$ & Hujan_712 & Hujan_717 & $\begin{array}{c}\text { Daun bendera belah } \\
\text { per rumpun (\%) }\end{array}$ & $\begin{array}{c}\text { Gabah rontok per } \\
\text { rumpun (butir) }\end{array}$ \\
\hline Ciapus & 0 & + & ++ & $56-100$ & $5-11$ \\
Fatmawati & 0 & + & ++ & $60-100$ & $10-22$ \\
HIPA 6 & 0 & + & ++ & $70-98$ & $15-25$ \\
Inpari 10 & 0 & + & ++ & $55-100$ & $12-18$ \\
Way Apo Buru & 0 & + & ++ & $60-100$ & $9-15$ \\
\hline
\end{tabular}

Keterangan: K-kontrol, Hujan_712: pukul 07.00-12.00 WIB, Hujan_717: pukul 07.00-17.00 WIB; + : patah 1-2 daun, ++: patah > 3 daun; MSP-minggu setelah mulai perlakuan; ${ }^{2}$ tidak dilakukan uji statistik

aksisnya kecil, namun sayangnya besaran sudut aksis tidak diukur. Penyebab mengecilkan sudut aksis pada malai dari perlakuan hujan masih belum diketahui. Setelah perlakuan Hujan 712 dihentikan, sudut aksis beberapa malai melebar pada sore hari (Gambar 2C), walaupun sudut tersebut lebih kecil dibandingkan dengan malai dari tanaman kontrol. Pada perlakuan Hujan_717, malai tetap bergerombol sepanjang hari dan malai tidak merunduk seperti pada kontrol. Ada kemungkinan sudut aksis yang berimplikasi pada arsitektur malai berkaitan dengan laju evapotranspirasi yang terhambat akibat kelembaban sekitar tanaman yang tinggi selama perlakuan hujan. Pada kondisi lapang, arsitektur malai padi dipengaruhi oleh dosis pupuk nitrogen (Rahayu et al., 2018), dan genotipe tanaman (Ramadhan et al., 2018).

Terdapat titik-titik kondensasi air di dalam sekam yang mengindikasikan bunga padi selalu lembab selama perlakuan hujan (Gambar 2D). Secara visual, sebagian sekam padi berwarna lebih terang dibandingkan dengan sekam pada tanaman kontrol. Ada sekam yang menunjukkan lebar bukaan lemma-palea saat anthesis tidak selebar bukaan lemma-palea pada tanaman kontrol. Sebagian sekam yang lain dari perlakuan hujan (Hujan_712 dan 717) ada yang berwarna coklat yang lebih gelap. Masih belum diketahui, apakah warna kecoklatan tersebut ada hubungannya dengan keberhasilan anthesis. Pada penelitian ini sulit dikesampingkan adanya kemungkinan kualitas air menjadi penyebab munculnya warna kecoklatan. Menurut Barang dan Saptomo (2019) kualitas air bersih di IPB masih berfluktuasi pada TDS yakni 47.35-56.68 $\mathrm{mg} \mathrm{L}^{-1}$, tingkat kekeruhan 1.76-2.60 NTU, dan pH 6.38-7.36.

Perlakuan hujan juga menyebabkan pelepah (upih) daun bendera yang patah (Tabel 2). Tanaman didera Hujan 717 memiliki jumlah pelepah daun bendera patah yang lebih banyak dibandingkan dengan tanaman Hujan_712. Penyebab seludang patah saat perlakuan diduga karena adanya peningkatan beban daun akibat adanya massa air yang terus menerus, walaupun posisi sprinkler telah diatur untuk meminimalisir efek tekanan air. Kerusakan pelepah tersebut perlu kajian lebih lanjut khususnya terkait dengan potensi serangan penyakit. Menurut Dutta dan Kalha (2011) serangan penyakit bercak pelepah sering terjadi setelah curah hujan tinggi selama beberapa hari diikuti dengan kelembaban udara $>90 \%$ dan suhu udara sekitar $30{ }^{\circ} \mathrm{C}$. Menurut Pal et al. (2017) curah hujan $100 \mathrm{~mm}$ per hari merupakan triger utama infeksi penyakit bercak pelepah. Hubungan antara curah hujan tinggi dengan peningkatan kejadian penyakit bercak batang dan pelepah pada tanaman padi telah diteliti secara intensif (Dutta dan Kalha, 2011; Bhukal et al., 2015; Pal et al., 2017; Weng et al., 2017; Parveen et al., 2018; Turaidar et al., 2018; Sabes et al.,

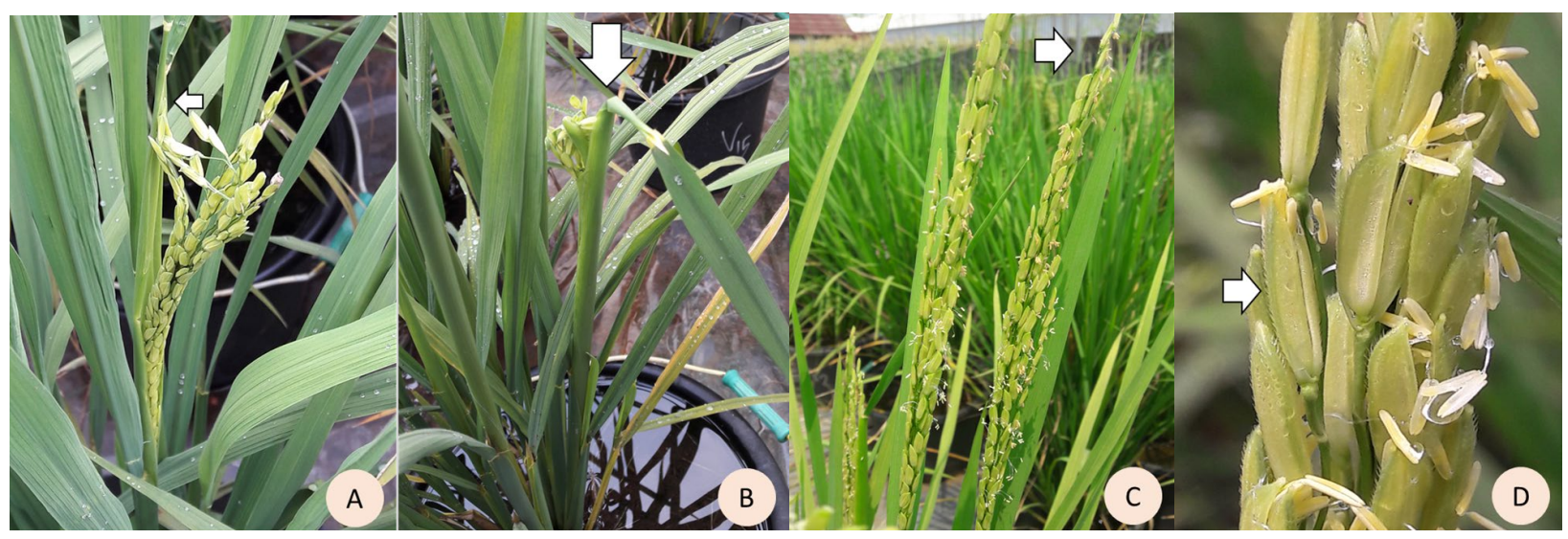

Gambar 2. Pengaruh perlakuan hujan pada tanaman padi. A. Malai abnormal bulir tersangkut pelepah daun bendera, B. Pelepah daun bendera patah (panah), C. Malai bergerombol, D. Bulir berisi embun air (panah) 
2020). Menurut Lu et al. (2018) padi yang memiliki daun lebih tegak lebih tahan deraan hujan.

\section{Bobot Gabah}

Perlakuan angin menurunkan bobot gabah isi pada semua genotipe yang diuji sebesar 29.50-70.24\% (Tabel 3). Penurunan bobot gabah isi terbesar terjadi pada genotipe Ciapus yakni $70.24 \%$ dan penurunan terendah terjadi pada genotipe Fatmawati yakni $29.50 \%$. Persen bobot gabah tidak-bernas yakni bobot gabah hampa ditambah gabah setengah hampa, relatif tidak terpangaruh perlakuan angin pada genotipe Fatmawati, yakni sebesar 7.52-10.90\% (ratarata 9.54\%). Pada genotipe lain, perlakuan angin nyata meningkatkan bobot gabah tidak-bernas yakni 165.83\%, $56.15 \%, 200.75 \%$, dan $34.77 \%$ secara berturut-turut pada genotipe Ciapus, HIPA 6, Inpari 10 dan WAB. Perlakuan angin juga menurunkan indeks 1,000 butir semua genotipe, yakni sebesar $21.24 \%$ pada Ciapus, $8.6 \%$ pada Fatmawati, $19.27 \%$ pada HIPA $6,10.62 \%$ pada Inpari 10 dan $10.18 \%$ pada WAB.
Tanaman padi perlakuan hujan menghasilkan bobot gabah isi lebih rendah yaitu pada Ciapus sebesar 24.0926.38\%, Fatmawati sebesar 19.21-34.43\% dan Inpari 10 sebesar 19.47-25.50\% (Tabel 3). Perlakuan Hujan_712 nyata menurunkan bobot gabah isi genotipe HIPA 6 sedangkan perlakuan Hujan_717 tidak berpengaruh nyata. Pada WAB perlakuan Hujan_712 tidak berpengaruh nyata sedangkan perlakuan Hujan_717 nyata menurunkan bobot gabah isi. Perbedaan respon genotipe HIPA 6 dan WAB perlu kajian lebih lanjut apakah disebabkan perbedaan fenologi atau ada mekanisme lain.

Bobot gabah hampa genotipe Ciapus, HIPA 6 dan WAB tidak terpengaruh perlakuan curah hujan (Tabel 3). Namun bobot gabah setengah hampa cenderung meningkat pada Ciapus dan HIPA 6, yang menunjukkan bahwa hujan mengganggu proses pengisian biji. Gangguan pada pengisian biji didukung nilai indeks bobot 1,000 butir yang lebih rendah pada perlakuan curah Hujan_717 pada semua genotipe dibandingkan Hujan 712.

Terdapat korelasi antara lama perlakuan hujan dengan tingkat kehampaan (Gambar 3, kanan), dengan

Tabel 3. Bobot gabah per rumpun tanaman padi pada perlakuan angin dan curah hujan

\begin{tabular}{|c|c|c|c|c|}
\hline Perlakuan & $\begin{array}{l}\text { Bobot gabah isi } \\
(\mathrm{g})\end{array}$ & $\begin{array}{l}\text { Bobot gabah hampa } \\
(\mathrm{g})\end{array}$ & $\begin{array}{c}\text { Bobot gabah setengah } \\
\text { hampa (g) }\end{array}$ & $\begin{array}{c}\text { Bobot } 1,000 \text { gabah isi } \\
(\mathrm{g})\end{array}$ \\
\hline & \multicolumn{4}{|c|}{ Ciapus } \\
\hline Kontrol & $111.11 \mathrm{a}$ & $7.25 \mathrm{a}$ & $2.18 \mathrm{~b}$ & $26.93 a$ \\
\hline Angin & $33.07 \mathrm{c}$ & $6.46 \mathrm{a}$ & $0.90 \mathrm{c}$ & $21.21 \mathrm{~b}$ \\
\hline Hujan_612 & $81.80 \mathrm{~b}$ & $5.91 \mathrm{a}$ & $2.06 \mathrm{~b}$ & $25.59 \mathrm{a}$ \\
\hline \multirow[t]{2}{*}{ Hujan_617 } & $84.34 b$ & $7.97 \mathrm{a}$ & $5.38 \mathrm{a}$ & $26.26 \mathrm{a}$ \\
\hline & \multicolumn{4}{|c|}{ Fatmawati } \\
\hline Kontrol & $111.12 \mathrm{a}$ & $12.16 \mathrm{a}$ & $2.15 \mathrm{a}$ & $25.23 \mathrm{a}$ \\
\hline Angin & $78.34 \mathrm{c}$ & $8.91 b$ & $1.34 \mathrm{~b}$ & $23.05 \mathrm{a}$ \\
\hline Hujan_612 & $89.77 b$ & $11.29 \mathrm{a}$ & $2.51 \mathrm{a}$ & $23.95 \mathrm{a}$ \\
\hline \multirow[t]{2}{*}{ Hujan_617 } & $72.86 b c$ & $6.05 b$ & $1.53 b$ & $24.44 \mathrm{a}$ \\
\hline & \multicolumn{4}{|c|}{ HIPA 6} \\
\hline Kontrol & $125.11 \mathrm{a}$ & $18.98 \mathrm{a}$ & $3.26 \mathrm{c}$ & $22.68 \mathrm{a}$ \\
\hline Angin & $53.64 \mathrm{c}$ & $15.45 b$ & $7.74 \mathrm{a}$ & $18.31 \mathrm{~b}$ \\
\hline Hujan_612 & $93.76 b$ & $18.77 \mathrm{a}$ & $5.53 b$ & $21.10 \mathrm{a}$ \\
\hline \multirow[t]{2}{*}{ Hujan_617 } & $123.10 \mathrm{ab}$ & $15.14 b$ & $3.98 \mathrm{c}$ & $19.79 b$ \\
\hline & \multicolumn{4}{|c|}{ Inpari 10} \\
\hline Kontrol & $133.32 \mathrm{a}$ & $8.60 \mathrm{~b}$ & $1.07 \mathrm{a}$ & $26.27 \mathrm{a}$ \\
\hline Angin & $61.68 \mathrm{c}$ & $13.76 \mathrm{a}$ & $0.63 \mathrm{a}$ & $23.48 \mathrm{c}$ \\
\hline Hujan_612 & $99.32 b c$ & $11.58 \mathrm{ab}$ & $1.43 \mathrm{a}$ & $25.41 \mathrm{ab}$ \\
\hline \multirow[t]{2}{*}{ Hujan_617 } & $107.36 b$ & $13.11 \mathrm{a}$ & $1.30 \mathrm{a}$ & $24.43 b$ \\
\hline & \multicolumn{4}{|c|}{ Way Apo Buru (WAB) } \\
\hline Kontrol & $89.99 a$ & $7.32 \mathrm{~b}$ & $1.10 \mathrm{a}$ & $24.36 \mathrm{a}$ \\
\hline Angin & $47.92 b$ & $5.46 \mathrm{c}$ & $1.03 \mathrm{a}$ & $21.88 b$ \\
\hline Hujan_612 & $91.58 \mathrm{a}$ & $7.26 \mathrm{~b}$ & $0.80 \mathrm{a}$ & $24.80 \mathrm{a}$ \\
\hline Hujan_617 & $39.31 \mathrm{~b}$ & $10.83 \mathrm{a}$ & $1.01 \mathrm{a}$ & $21.21 \mathrm{~b}$ \\
\hline
\end{tabular}

Keterangan: Angka pada kolom varietas sama diikuti huruf sama tidak berbeda nyata pada LSD $\alpha=5 \%$ 
tingkat korelasi tergantung genotipe. Semakin lama hujan, tingkat kehampaan nyata meningkat pada genotipe Ciapus, Inpari 10 dan WAB. Tingkat kehampaan pada genotipe Fatmawati dan HIPA 6 cenderung meningkat dari kontrol pada perlakuan hujan selama 5 jam dari pukul 07.00-12.00 lalu menurun pada perlakuan hujan selama 10 jam dari pukul 07.00-17.00. Respon genotipe yang berbeda antara Hujan_712 dengan Hujan_717 tersebut belum diketahui penyebabnya. Ada kemungkinan hujan pada sore hari dapat memulihkan potensi kehampaan yang terjadi akibat hujan pagi hari. Dugaan tersebut perlu diverifikasi lebih lanjut mengingat perlakuan hujan selama 5 jam dari pukul 12.0017.00 tidak dilakukan. Menurut Nurjani et al. (2013) 40\% kejadian angin kencang di Indonesia terjadi pada pukul $12.00-16.00,35 \%$ terjadi pada $16.01-00.00$, dan $14 \%$ terjadi pada 00.01-11.59 waktu setempat.

Pada genotipe sama, persen gabah hampa cenderung lebih tinggi pada tanaman dengan perlakuan angin daripada hujan (Gambar 3 kiri). Genotipe WAB relatif lebih sensitif terhadap curah hujan, sedangkan Ciapus, HIPA 6 dan Inpari 10 relatif lebih sensitif terhadap angin kencang. Genotipe Fatmawati diduga lebih tahan terhadap deraan angin dan curah hujan. Jadi, ada perbedaan sensitifivitas genotipe terhadap deraan angin kencang dan curah hujan. Secara umum, jumlah gabah hampa akan tinggi jika pada fase kritis yakni bunting dan berbunga tanaman tercekam suhu tinggi (Aghamolki et al., 2014) atau kekeringan (Yang et al., 2019). Kehampaan akibat deraan angin disebabkan oleh kegagalan penyerbukan dan kerusakan organ reproduksi (Ishimaru et al., 2012; Sridevi dan Chellamuthu, 2015). Perlu penelitian lebih lanjut faktor penentu kehampaan padi pada kedua deraan khususnya pada Fatmawati.

\section{Pengelolaan Produksi Berbasis Iklim}

Jian et al. (2020) melaporkan adanya peningkatan intensitas curah hujan per jam pada masa anthesis dan pengisian biji 0.9-2.8\% per dekade di China. Di Indonesia, lokasi yang mengalami kejadian seperti simulasi penelitian ini masih jarang dilaporkan, kecuali untuk Pulau Jawa dan Sumatera (Nurjani et al., 2013; Barung et al., 2019; Dulbari et al., 2021). Menurut Barung et al. (2019), terdapat kejadian hujan tanpa henti selama 23-37 hari di Sumatera pada 1995 dan selama 17 hari pada 1988; dan melalui simulasi, intensitas curah hujan hingga tahun 2040 akan meningkat 8.5-14.7\% per tahun, dan kejadian hujan tanpa henti dapat berlangsung selama 40 hari. Jika pada penelitian ini durasi hujan 15 hari berturut-turut seperti pada simulasi penelitian ini telah menyebabkan penurunan hasil gabah isi yang cukup besar, maka hujan yang lebih lama akan berdampak penurunan hasil yang lebih besar. Menurut Dulbari et al. (2021) terjadi 83 kejadian cuaca ekstrim di Provinsi Lampung yang menyebabkan kehilangan hasil padi sebesar 33.59 ribu ton GKG tahun 2015.

Banyak peneliti mengajukan skenario untuk mengurangi dampak perubahan iklim melalui penerapan pertanian cerdas iklim (Climate-Smart Agriculture-CSA), yang basisnya adalah manajemen air, varietas tahan kering, dan mengurangi emisi gas rumah kaca (Auffhammer et al., 2012; De Pinto et al., 2020; Tran et al., 2020). Di Indonesia, CSA untuk pertanaman padi akan lebih operasional jika basisnya adalah untuk menekan kerugian hasil berdasarkan skenario cuaca ekstrim yakni curah hujan tinggi dan angin kencang, karena kedua hal tersebut diprediksi akan semakin ekstrim pada masa mendatang (Barung et al., 2019). Selain itu, curah hujan tinggi juga erat kaitanya dengan peningkatan serangan penyakit karat padi (Chowdhury et al., 2015; Parveen et al., 2018).

Agar manajemen produksi berbasis iklim (climatesmart production) dapat dijalankan dengan baik di Indonesia, diperlukan beberapa prasyarat. Pertama adalah memilih varietas padi yang tepat karena genotipe padi memiliki sensitivitas berbeda-beda.

Kedua adalah menyusun data risiko iklim secara spasial dan temporal (Dhamira dan Irham, 2020). Dari 345 zona agroklimat di Indonesia sebagian besar adalah daerah rawan angin kencang dan curah hujan tinggi (http:// www.bmkg.go.id). Jawa Tengah sebagai contoh, memiliki prevalensi angin kencang yang tinggi pada bulan OktoberDesember, Maret-April, dan Juli-September (Nurjani et al., 2013). Dulbari et al. (2021) menyatakan bahwa kejadian cuaca ekstrim di Provinsi Lampung terjadi pada Januari-Maret atau bulan bercurah hujan tinggi. Sebaran risiko cuaca ekstrim umumnya mengikuti pola curah hujan bulanan dan juga tipe hujan setempat. Menurut Tukidi (2010), Indonesia memiliki tiga tipe hujan (Gambar 4BD). Menurut Dulbari et al. (2021) kejadian cuaca ekstrim bersifat lokal dan insidentil, tetapi Santosa et al. (2020) mencatat adanya kejadian berulang pada wilayah tertentu. Untuk itu, ketersediaan data iklim time series dan real time adalah sangat penting.

Ketiga adalah mengumpulkan data luas tanam time series. Surmaini dan Syahbuddin (2016) mengemukakan bahwa waktu tanam padi dipengaruhi oleh musim, yang diformulasikan menjadi kalender tanam dari otoritas setempat. Menurut Sumarno (2006), periodisasi tanam padi di Indonesia ada tiga yakni tanam utama, gadu dan tanam kemarau (Tabel 4). Fase kritis padi terhadap cekaman adalah masa generatif (Shah et al., 2011; Aghamolki et al., 2014; Sridevi dan Chellamuthu, 2015; Dulbari, 2017; Yang et al., 2019). Walaupun umur padi dapat berbeda, tetapi lama fase generatif hampir sama yakni 65 hari (Gambar 1). Irisan dari luas tanam, fase kritis, dan kejadian cuaca ekstrim dapat digunakan untuk memprediksi risiko hasil pada satu wilayah. Dengan demikian, jadwal tanam padi juga diikuti profil risiko hasil (Ishimaru et al., 2012; Surmaini dan Syahbuddin, 2016).

Keempat, mencatat data input produksi khususnya jenis dan dosis pupuk serta jarak tanam karena hal tersebut berkorelasi dengan kerentanan rebah (Zhang et al., 2017; Santosa et al., 2020). Data agronomis sangat penting untuk menghindari over- ataupun under-estimate dari prediksi yang digunakan.

Selain empat langkah mitigasi dampak cuaca ekstrim seperti di atas, juga perlu dilakukan langkah adaptasi di lapangan. Langkah adaptasi secara umum dilakukan dengan 

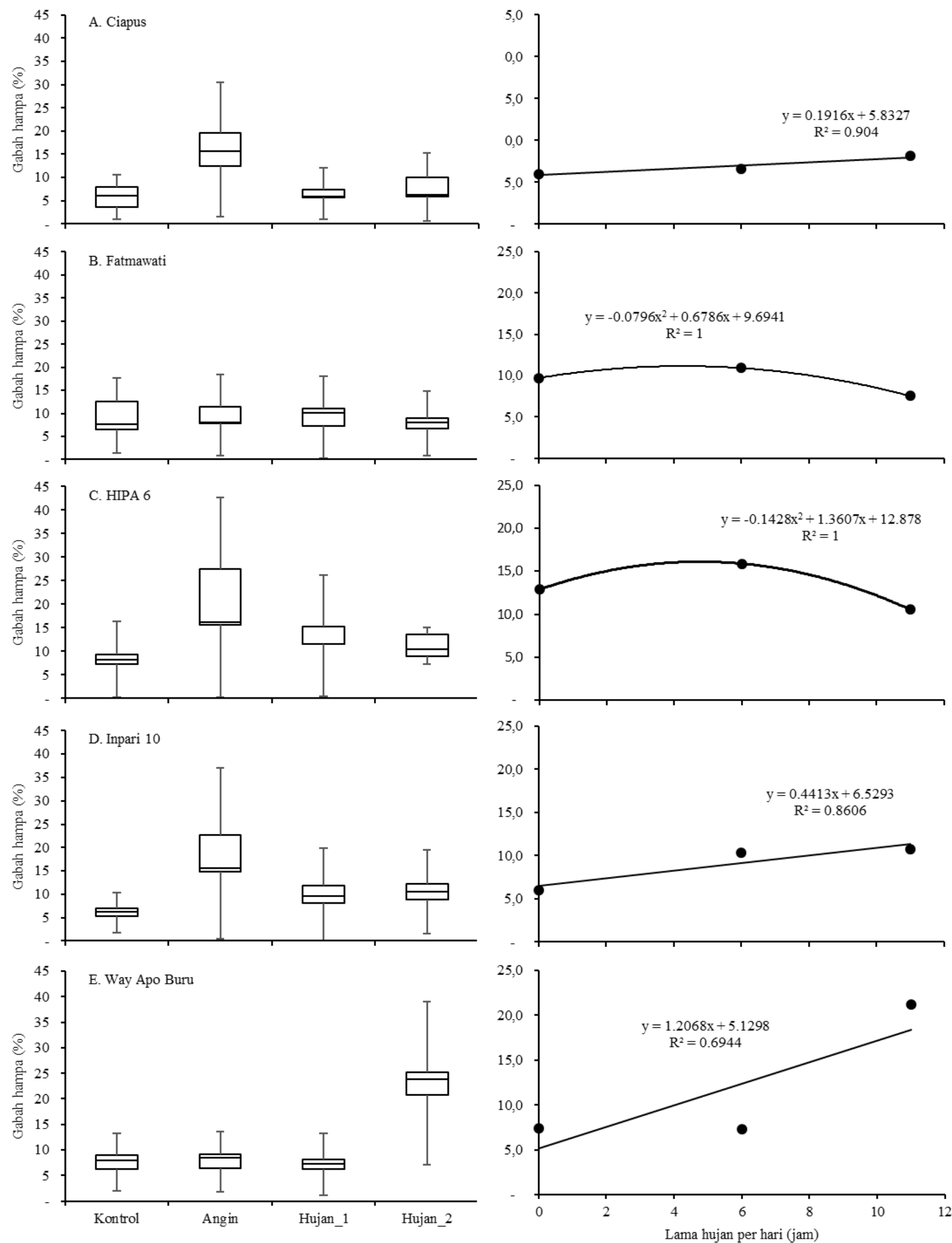

Gambar 3. Persentase gabah hampa genotipe padi pada perlakuan angin dan curah hujan (kiri), dan korelasi antara lama hujan dengan persentase hampa (kanan) 

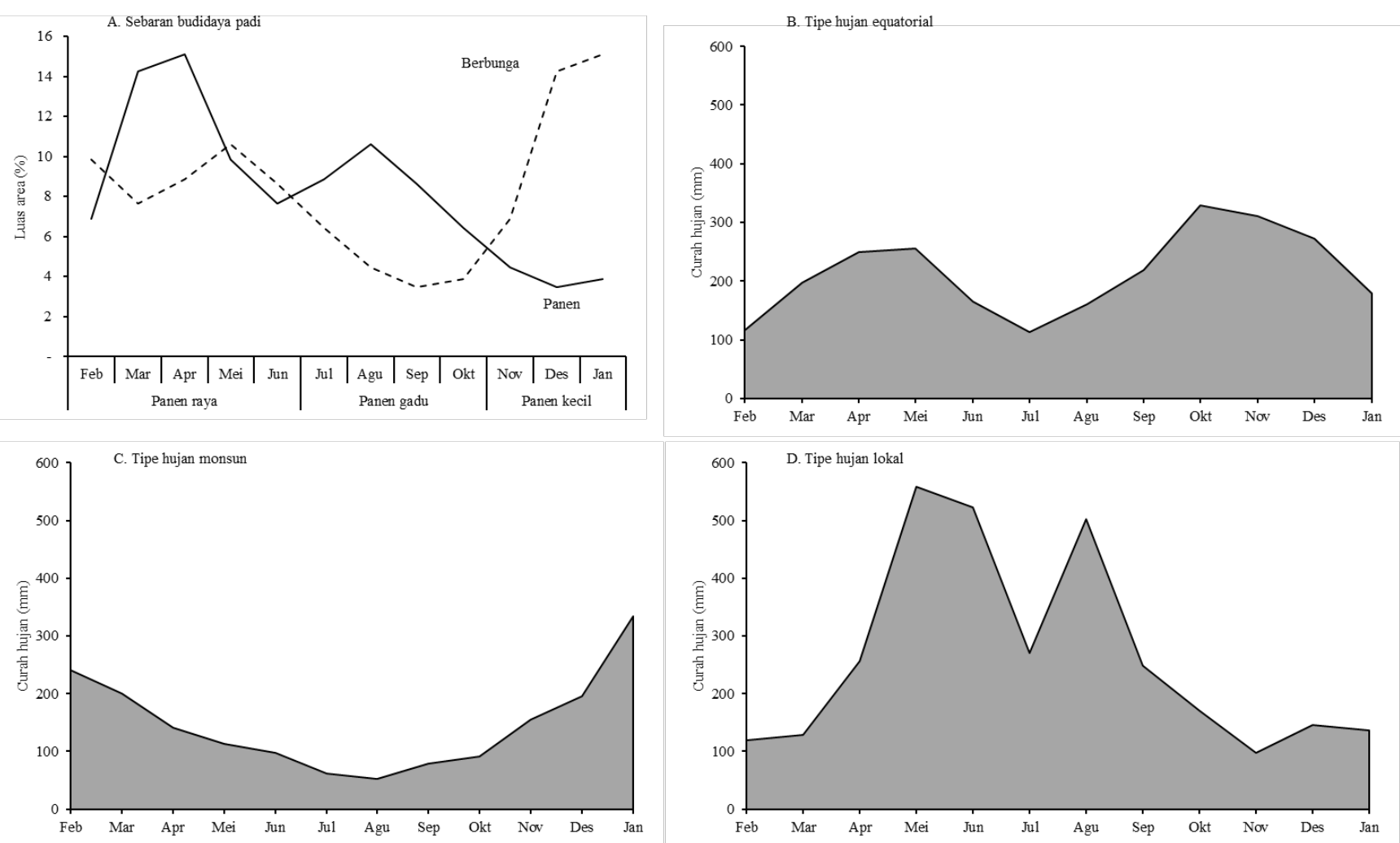

Gambar 4. Sebaran pertanaman padi dan curah hujan bulanan. A. Luas panen dan estimasi luas areal padi berbunga (BPS, 2020a; 2020b). Data B, C, D diadopsi dari Tukidi (2010)

Tabel 4. Periodisasi musim tanam dan luas panen padi di Indonesia

\begin{tabular}{|c|c|c|c|c|c|c|}
\hline \multicolumn{2}{|c|}{ Periodisasi tanam ${ }^{z}$} & \multicolumn{2}{|c|}{ Periodisasi panen ${ }^{2}$} & \multicolumn{3}{|c|}{ Sebaran luas panen (\%) } \\
\hline Kriteria & Bulan & Kriteria & Bulan & $2018^{y}$ & $2019^{y}$ & $2020^{\mathrm{x}}$ \\
\hline \multirow[t]{5}{*}{ Tanam utama } & November & Panen raya & Februari & 9.41 & 6.85 & 4.37 \\
\hline & Desember & & Maret & 15.57 & 16.14 & 11.06 \\
\hline & Januari & & April & 12.40 & 15.76 & 17.19 \\
\hline & Februari & & Mei & 8.80 & 8.63 & 12.08 \\
\hline & Maret & & Juni & 7.83 & 8.26 & 6.88 \\
\hline \multirow[t]{4}{*}{ Tanam gadu } & April & Panen gadu & Juli & 9.41 & 8.91 & 8.27 \\
\hline & Mei & & Agustus & 9.59 & 11.07 & 11.15 \\
\hline & Juni & & September & 8.88 & 7.50 & 9.48 \\
\hline & Juli & & Oktober & 5.54 & 5.63 & 8.09 \\
\hline \multirow{3}{*}{$\begin{array}{l}\text { Tanam } \\
\text { kemarau }\end{array}$} & Agustus & Panen kecil & November & 4.57 & 4.41 & 4.37 \\
\hline & September & & Desember & 3.25 & 3.00 & 4.09 \\
\hline & Oktober & & Januari & 4.75 & 3.85 & 2.97 \\
\hline
\end{tabular}

Keterangan: ${ }^{\mathrm{D}}$ Diadopsi dari Sumarno (2016); ${ }^{\mathrm{y}}$ Sumber BPS (2020a), ${ }^{\mathrm{x}}$ Sumber BPS (2020b)

cara mengatur iklim mikro, memilih varietas yang tepat, mengatur jarak tanam, mengatur waktu tanam, dan memupuk secara berimbang (Sridevi dan Chellamuthu, 2015; Santosa et al., 2016; Dulbari, 2017; Zhang et al., 2017; Santosa et al., 2020). Santosa et al. (2016) menekankan perlunya menanam tanaman turi di pematang sawah sebagai penahan angin (wind breaker).

\section{KESIMPULAN}

Deraan angin dan hujan menurunkan bobot gabah isi dan meningkatkan gabah hampa dengan besaran tergantung genotipe. Way Apu Buru relatif lebih sensitif terhadap curah hujan, sedangkan Ciapus, HIPA 6 dan Inpari 10 relatif lebih sensitif terhadap angin. Genotipe Fatmawati relatif 
lebih tahan terhadap kedua deraan dibandingkan genotipe lain. Dalam rangka menerapkan manajemen produksi cerdas iklim, diperlukan dukungan data agronomis dan non agronomis, serta langkah adaptasi di lapangan untuk mengurangi dampak cuaca ekstrim. Selain itu, perlu kajian lebih lanjut mekanisme kehampaan pada kedua deraan dalam rangka meningkatkan efektivitas adaptasi terhadap perubahan iklim.

\section{UCAPAN TERIMAKASIH}

Terimakasih kepada Kementerian Riset dan Teknologi/ BRIN) Republik Indonesia yang telah mendanai penelitian skema Hibah Kompetensi Tahun 2017-2018 dengan judul "Mitigasi dan Adaptasi Tanaman Padi pada Deraan Cuaca Ekstrim"

\section{DAFTAR PUSTAKA}

[BPS] Badan Pusat Statistik. 2020a. Luas panen dan produksi padi di Indonesia 2019. Berita Resmi Statistik 16/02/Th.XXII. https://www.bps.go.id [12 Desember 2020].

[BPS] Badan Pusat Statistik. 2020b. Luas panen dan produksi padi di indonesia tahun 2020 (angka sementara). Berita Resmi Statistik 79/10/Th.XXII. https://www. bps.go.id. [12 Desember 2020].

Aghamolki, M.T.K., M.K. Yusop, F.C. Oad, H. Zakikhani, H.Z. Jaafar, S. Kharidah, M.H. Musa. 2014. Heat stress effects on yield parameters of selected rice cultivars at reproductive growth stages. J. Food Agric. Environ. 12:741-746.

Auffhammer, M., V. Ramanathan, J. Vincent. 2012. Climate change, the monsoon, and rice yield in Indian. Clim. Change 111:411-424.

Baker, C.J., M. Sterling, P. Berry. 2014. A generalized model of crop lodging. J. Theor. Biol. 363:1-12. Doi:10.1016/j.jtbi.2014.07.032.

Barang, M.H.D., S.K. Saptomo. 2019. Analisis kualitas air pada jalur distribusi air bersih di gedung baru Fakultas Ekonomi dan Manajemen Institut Pertanian Bogor. J-SIL 4:13-24. Doi:10.29244/jsil.4.1.13-24.

Barung, F.M., I.D.G.A. Putra, H.M. Gultom. 2019. Proyeksi indek iklim ekstrim di pulau Sumatera. hal. 274284. Dalam Prosiding Seminar Nasional Bumi dan Atmosfer 2019: Enhancing Knowledge of the SunEarth System for Weather Action. Tangerang 21 Maret 2019.
Bhukal, N., R. Singh, N. Mehta. 2015. Progression and development of sheath blight of rice in relation to weather variables. J. Mycol. Plant Pathol. 45:166172.

Chowdhury, M.T.I., M.S. Mian, M.A.T. Mia, M.Y. Rafii, M.A. Latif. 2015. Agro-ecological variations of sheath rot disease of rice caused by Sarocladium oryzae and DNA fingerprinting of the pathogen's population structure. Genet. Mol. Res. 14:18140-52. Doi:10.4238/2015.December.23.1.

De Pinto, A., N. Cenacchi, H-Y. Kwon, J. Koo, S. Dunston. 2020. Climate smart agriculture and global food-crop production. PLoS ONE 15: e0231764.

Dhamira, A., I. Irham. 2020. The impact of climatic factors on rice production in Indonesia. Agro Ekon. 31:4660. Doi:10.22146/ae.55153.

Dulbari, D., E. Santosa, Y. Koesmaryono, E. Sulistyono, A. Wahyudi, H. Agusta, D. Guntoro. 2021. Local adaptation to extreme weather and it's implication on sustainable rice production in Lampung, Indonesia. Agrivita J. Agric. Sci. 43:125-136.

Dulbari, E. Santosa, E. Sulistyono, Y. Koesmaryono. 2017. Adaptation of wetland rice to extreme weather. J. Trop. Crop Sci. 4:70-77. Doi:10.29244/jtcs.4.2.7077.

Dutta, U., C.S. Kalha. 2011. Effect of meteorological parameters on development of sheath blight disease in paddy. Plant Disease Res. 26:122-126.

He, W., Y. Liu, H. Sun, F. Taghizadeh-Hesary. 2020. How does climate change affect rice yield in China? Agriculture 10:441. Doi:10.3390/agriculture10100441.

Ishimaru, T., H. Hirabayashi, T. Kuwagata, T. Ogawa, M. Kondo. 2012. The early-morning flowering trait of rice reduces spikelet sterility under windy and elevated temperature conditions at anthesis. Plant Prod. Sci. 15:19-22. Doi:10.1626/pps.15.19.

Jian, Y., J. Fu, B. Li, F. Zhou. 2020. Increased extreme hourly precipitation over China's rice paddies from 1961 to 2012. Sci. Rep. 10:10609. Doi:10.1038/s41598-02067429-0.

Lu, H., X. Qi, X. Guo, J.J. Towa, B. Zhen, D. Qiao, Z. Wang, B. Yang, Y. Han. 2018. Canopy light utilization and yield of rice under rain-catching and controlled irrigation. Water 10:1340. Doi:10.3390/w10101340. 
Martinez-Vazquez, P. 2016. Crop lodging induced by wind and rain. Agric. Forest Meteorol. 228-229:265-275. Doi:10.1016/j.agrformet.2016.07.003 0168-1923.

Myhre, G., K. Alterskjær, C.W. Stjern, Ø. Hodnebrog, L. Marelle, B.H. Samset, J. Sillmann, N. Schaller, E. Fischer, M. Schulz, A. Stohl. 2019. Frequency of extreme precipitation increases extensively with event rareness under global warming. Sci. Rep. 9: 16063. Doi:10.1038/s41598-019-52277-4.

Niu, L., S. Feng, W. Ding, G. Li. 2016. Influence of speed and rainfall on large-scale wheat lodging from 2007 to 2014 in China. PLoS ONE 11: e0157677.

Nurjani, E., A. Rahayu, F. Rachmawati. 2013. Kajian bencana angin ribut di Indonesia periode 1990-2011: upaya mitigasi bencana. Geomedia 11:191-206.

Pal, R., D. Mandal, M.K. Biswas, B.N. Panja. 2017. Effect of weather parameters on the initiation and progression of sheath blight of rice. J. Agrometeorology 19:3943.

Parveen, S., M.R. Bhuiwan, M.A.I. Khan, M.A. Ali. 2018. Effect of planting time on sheath blight disease of rice in Bangladesh. Bangladesh Rice J. 22:55-62. Doi:10.3329/brj.v22i2.44042.

Rahayu, S., M. Ghulamahdi, W.B. Suwarno, H. Aswidinnoor. 2018. Morfologi malai padi (Oryza sativa L.) pada beragam aplikasi pupuk nitrogen. J. Agron. Indonesia 46:145-152. Doi:10.24831/jai.v46i2.18092.

Ramadhan, F., W.B. Suwarno, A. Nindita, H. Aswidinnoor. 2018. Analisis genetik arsitektur malai padi menggunakan dua populasi F2. J. Agron. Indonesia 46:1-8

[RKB] Rice Knowledge Bank. 2020. Learn about best practices in rice farming. http://www.knowledgebank. irri.org. [12 Desember 2020].

Sabes, P.L.P., M.M. Lon, M.A. Peter, J. Maruyama, S. Koyama, T. Watanabe, S. Koizumi. 2020. Effect of increased silicon content of paddy rice on sheath blight development through carbonized rice husk application. JARQ. 54:145-151.

Santosa, E., Dulbari, H. Agusta, D. Guntoro, S. Zaman. 2016. Phenomenon of lodging and its implication on improvement of rice adaptive to extreme weather in Indonesia. In Proceeding of National Seminar
PERIPI 'Breeding Strategy for Global Climate Change Anticipation'. Pp. 45-53. Pekanbaru-Riau, Indonesia. 20 July 2016.

Santosa, E., H. Agusta, D. Guntoro, S. Zaman. 2020. Strength assessment of rice hills from different planting distance by loading simulation. Agric. Sci. 5:131-139.

Shah, F., J. Huang, K. Cui, L. Nie, T. Shah, C. Chen, K. Wang. 2011. Impact of high-temperature stress on rice plant and its traits related to tolerance. J. Agric. Sci. 149:545-556. Doi:10.1017/S0021859611000360.

Sheikh, M.M., N. Manzoor, J. Ashraf, M. Adnan, D. Collins, S. Hameed, M. J. Manton, A. U. Ahmed, S.K. Baidya, H.P. Borgaonkar, N. Islam, D. Jayasinghearachchi, D.R. Kothawale, K.H.M.S. Premalal, J.V. Revadekar, M.L. Shrestha. 2015. Trends in extreme daily rainfall and temperature indices over South Asia. Int. J. Climatol. 35:1625-1637. Doi:10.1002/joc.4081.

Sridevi, V., V. Chellamuthu. 2015. Impact of weather on rice - a review. Int. J. Appl. Res. 1:825-831.

Su, P., X-L. Liao, Y. Zhang, H. Huang. 2012. Influencing factors on rice sheath blight epidemics in integrated rice-duck system. J. Integrative Agric. 11:14621473.

Sumarno. 2016. Periodisasi musim tanam padi sebagai landasan manajemen produksi beras nasional. Sinar Tani 36(3136). Tahun XXXVI.

Suprihatno, B., A.A. Daradjat, Satoto, Baehaki, I.N. Widiarta, A. Setyono, S.D. Indrasari, O.S. Lesmana, H. Sembiring. 2009. Deskripsi Varietas Padi. Subang: Balai Besar Penelitian Tanaman Padi. Badan Litbang Pertanian, Departemen Pertanian, RI.

Surmaini, E., H. Syahbuddin. 2016. Kriteria awal musim tanam: tinjauan prediksi waktu tanam padi di Indonesia. J. Litbang Pert. 35:47-56.

Tran, N.L.D., R.F. Rañola, B.O. Sander, W. Reiner, D.T. Nguyen, N.K.N. Nong. 2020. Determinants of adoption of climate-smart agriculture technologies in rice production in Vietnam. Internat. J. Clim. Change Strategies Manag. 12:1756-8692. Doi:10.1108/ IJCCSM-01-2019-0003.

Tukidi. 2010. Karakter curah hujan di Indonesia. J. Geografi 7:136-145. 
Turaidar, V., M. Reddy, R. Anantapur, K.N. Krupa, N. Dalawai, C.A. Deepak, K.M.H. Kumar. 2018. Rice sheath blight: major disease in rice. Int. J. Curr. Microbiol. App. Sci. Special Issue- 7:976-988.

Weng, F., W. Zhang, X. Wu, X. Xu, Y. Ding, G. Li, Z. Liu, S. Wang. 2017. Impact of low-temperature, overcast and rainy weather during the reproductive growth stage on lodging resistance of rice. Sci Rep 7:46596. Doi:10.1038/srep46596.
Yang, X., B. Wang, L. Chen, P. Li, C. Cao. 2019. The different influences of drought stress at the flowering stage on rice physiological traits, grain yield, and quality. Sci. Rep. 9:3742. Doi:10.1038/s41598-01940161-0.

Zhang, W., L. Wu, Y. Ding, X. Yao, X. Wu, F. Weng, G. Li, Z. Liu, S. Tang, C. Ding, S. Wang. 2017. Nitrogen fertilizer application affects lodging resistance by altering secondary cell wall synthesis in japonica rice (Oryza sativa). J. Plant Res. 130:859-871. Doi:10.1007/s10265-017-0943-3. 